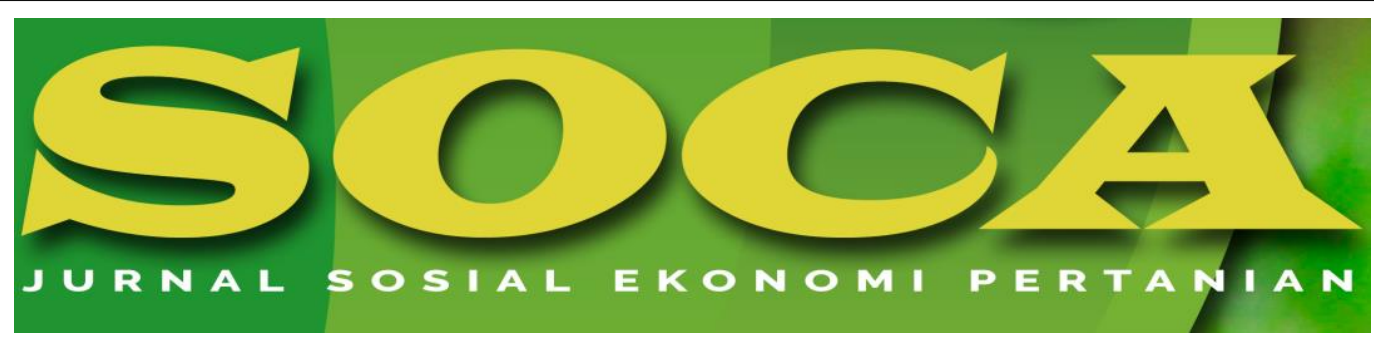

https://ojs.unud.ac.id/index.php/soca

\title{
Pre-Seed, Seed, and Start-Up Business on the Vegetable Seller e-Commerce User in Bali Province
}

\author{
Gede Mekse Korri Arisena, I Nyoman Gede Ustriana, and Anak Agung Inten Trisna \\ Agribusiness Department, Agricultural Faculty, Udayana University \\ Email: korriarisena@unud.ac.id \\ Handphone: 081944864138
}

Submitted: April 5th, 2020; Revised: April 23th, 2020; Accepted: May 17th, 2020

\begin{tabular}{ll}
\hline & Abstract \\
Keywords: & Today, many efforts prepared to improve the scope of the agricultural \\
Business; & commodity product marketing segment to make the consumer and \\
Vegetable & building an e-Commerce based agricultural trading system. This \\
Seller; E- & study aimed to assess the pre-seed, seed and start-up business on \\
Commerce & the vegetable seller e-Commerce user in Bali Province. This study \\
& done on the e-Commerce platforms: Facebook, Instagram, \\
& Tokopedia, and Shopee that used by the vegetable seller e- \\
Commerce user in Bali Province. There were 30 participants involved \\
in this study. Qualitative descriptive analysis with simple data \\
tabulation used to address the study aim. Results showed that the \\
pre-seed business developed due to the owner's hobby in the \\
agricultural area and environmental factors that drove them to run \\
an agribusiness. On the step of the seed business, the vegetable \\
seller started the business according to their will. Most of the sellers \\
still used social media-based e-commerce with a simple application \\
module. They expect to develop a complete module system to run \\
their e-Commerce based business in the future.
\end{tabular}

How to Cite (APA 6th Style):

Arisena, G. M. K., Ustriana, I. N. G., \& Trisna, A. A. I. (2020). Pre-Seed, Seed, and Start-Up Business on the Vegetable Seller e-Commerce User in Bali Province. SOCA: Jurnal Sosial Ekonomi Pertanian, 14(3), 532-545. https: //doi.org/https://doi.org/ 10.24843/SOCA.2020.v14.i03.p14 


\section{INTRODUCTION}

Apriadi and Saputra (2017) stated that the classic problem in an agricultural field was the distribution chain. Some community, farmer, and consumer parties were receiving a significant disadvantage due to this long distribution chain. The long distribution chain usually happens because of the domination of the seller (local collector agent, major collector agent, and exporter). This domination didn't give any added value to the distributed product, but still taken the margin.

Apriadi and Saputra (2017) explained that to provide an agricultural product proper price, e-Commerce based-trading system in the agricultural field must be built. e-Commerce based-trading system was an alternative offered to the farmer to cut the long distribution chain by simplifying the promoting, publishing, and disseminating process. Nugraha and Wahyuhastuti (2017) also stated the business activity trend of the internet user was encouraging the development of a start-up business. Most start-up businesses provided trading and services to meet the community daily need. A new digital start-up appeared quickly in each minute with similar features. Therefore skill, innovation, and creativity which majorly presented by the young generation could be applied to build a start-up company.

The advantage produced by internet marketing named 5S: sell, serve, speak, save, and sizzle (Table 1). The benefit of internet marketing has broadened the level of distribution, disseminating information for product development, creating two-way communication, decreasing cost, and giving a friendly impression.

Table 1. $5 \mathrm{~S}$ of Internet Marketing

\begin{tabular}{|c|c|c|}
\hline Component & Benefit & Specific Purpose \\
\hline Sell & $\begin{array}{l}\text { Reached by expanding } \\
\text { the range of product } \\
\text { distribution }\end{array}$ & $\begin{array}{l}\text { - Increase } 10 \% \text { of online sale } \\
\text { in the market } \\
\text { - Increase } 20 \% \text { of online sale } \\
\text { in a year }\end{array}$ \\
\hline $\begin{array}{l}\text { Serve-Presenting Added } \\
\text { Values }\end{array}$ & $\begin{array}{l}\text { Reached by giving } \\
\text { online added-value on } \\
\text { the customer and } \\
\text { information about the } \\
\text { product development } \\
\text { by an online dialog and } \\
\text { feedback. }\end{array}$ & $\begin{array}{l}\text { - Improving the interaction } \\
\text { with various type of sites } \\
\text { - Improving } 10 \% \text { duration of } \\
\text { stay in the site } \\
\text { - Improving the number of } \\
\text { online customers at least } \\
30 \% \text { in a month }\end{array}$ \\
\hline $\begin{array}{l}\text { Speak- Getting Closer } \\
\text { with the Consumer }\end{array}$ & $\begin{array}{l}\text { Creating two-way } \\
\text { communication on } \\
\text { web and email in the } \\
\text { market study through } \\
\text { formal and informal } \\
\text { survey by monitoring } \\
\text { the chat room and } \\
\text { reach the customer by } \\
\text { using the public } \\
\text { relation division. }\end{array}$ & $\begin{array}{l}\text { - Improving the range of the } \\
\text { email sent to } 50 \% \text { from the } \\
\text { customer database } \\
\text { - Conducting a survey that } \\
\text { involves } 1,000 \text { customers in } \\
\text { a month } \\
\text { - Improving the number of } \\
\text { visitation to the website }(5 \%)\end{array}$ \\
\hline
\end{tabular}




\begin{tabular}{|c|c|c|}
\hline Save- Saving the Cost & $\begin{array}{l}\text { Reached by online } \\
\text { communication } \\
\text { through email, sale, } \\
\text { and online transaction } \\
\text { service to decrease the } \\
\text { utilization of staff and } \\
\text { reducing the postal } \\
\text { shipping cost. }\end{array}$ & $\begin{array}{l}\text { - Increasing the } 10 \% \text { of the } \\
\text { sale with the same amount } \\
\text { of budget } \\
\text { - Reducing } 15 \% \text { of direct sale } \\
\text { cost by conducting an email } \\
\text { transaction }\end{array}$ \\
\hline $\begin{array}{l}\text { Sizzle- Expanding the } \\
\text { online merk }\end{array}$ & $\begin{array}{l}\text { Reached by providing } \\
\text { suggestion and online } \\
\text { experience to show the } \\
\text { friendly impression to } \\
\text { the customer. }\end{array}$ & $\begin{array}{l}\text { Increasing the branding } \\
\text { metrics such as awareness of } \\
\text { certain merk and preference } \\
\text { in buying or desiring certain } \\
\text { merk. }\end{array}$ \\
\hline
\end{tabular}

Source : Chaffey, et al. (2006) in Antara, et.al (2017)

Perdani, et.al (2018) elaborated the e-Commerce potency and digital business application for the entrepreneur. They also invited the entrepreneur candidate to build a start-up business. Start-up was defined as a company that run by utilizing information technology and the internet. More further, Silalahi (2017) also explained that there was no standard definition of a start-up business. But the general consensus stated that a start-up company is a form of small-medium enterprise that moved on the information technology area and emphasizing the use of e-commerce platforms. Inadequate capital amount in this step contributed to a phenomenon called "missing middle", a situation where the start-up company growth synchronization stop when try to reach the upper-middle level. A start-up company was at risk of losing its market, experiencing great loss, and end on the bankrupt situation in this "missing middle" phenomenon. This process could get severe when some start-up companies were also moving in the same area of business.

The novelty of this study was the assessment of the pre-seed and seed step in the business process. Pre-seed was a step before the idea or creativity in digital business appeared, an initial step takes before the agribusiness entity formed, the candidate of the business owner still try various ideas about the digital business and find information from the variety of sources of things needed in building a business. Seed was a step taken when the owner developing their idea and creativity based on their knowledge and ability to start a start-up business. This study aimed to assess the pre-seed, seed, and start-up on the vegetable seller e-Commerce user in Bali Province.

\section{RESEARCH METHODS}

This study was done on the e-commerce platform: Facebook, Instagram, Tokopedia, and Shopee. Those platforms chosen by purposive sampling technique due to the sale specialization on the online vegetable selling. The location of the vegetable seller located in Bali Province because of some reason: (1) Bali was the 
tourism industry and (2) Bali was also an agricultural sector industry. The data collection conducted from January to March 2020.

The primary data obtained directly from the vegetable seller through interviews and guided by the questionnaire. While the secondary data obtained from the previous study aimed to know the use of the e-commerce on a marketing process and book about the marketing management, e-commerce, and e-marketing. The interview was done by using a list of questions about the study variables prepared prior to the interview.

The study population was all vegetable sellers domiciled in Bali Province and promoting their vegetable by using e-commerce on four online platforms provided: Facebook, Instagram, Shopee, and Tokopedia. This study involved 30 vegetable sellers. On the Instagram and Facebook platform, we searched for the hashtag of \# sayuranbali (Bali Vegetable), \# sayurmurah (cheap vegetable), \#hidroponikbali (Bali hydroponic), \#jualsayur (selling vegetable), etc. to find the customer account. Then we selected the vegetable seller to participate in the study. By using the shopee and tokopedia platform, we searched for the keyword of "sayur segar" (fresh vegetable), "pakcoy" (bok coy), "sawi" (green mustard) etc. on the search icon provided by the platform. The location was filtered using the location filter. We were assuring the location set in Bali Province. After that, we contacted the vegetable seller to join the study.

A descriptive qualitative analysis with simple data tabulation used to address the study aim that was to assess the pre-seed, seed, and start-up business vegetable seller e-commerce user in Bali Province.

\section{RESULT AND DISCUSSION Pre-Seed Business}

Pre-seed was a step before the idea or creativity in digital business appeared, an initial step takes before the agribusiness entity formed, the candidate of the business owner still try various ideas about the digital business and find information from the variety of sources of things needed in building a business. The pre-seed business participant in Bali Province is shown in Table 2.

Table 2. Pre-Seed Business

\begin{tabular}{ccl}
\hline No & $\begin{array}{l}\text { Participant's } \\
\text { Code Number }\end{array}$ & \multicolumn{1}{c}{ Pre-Seed } \\
\hline 1 & 1 & $\begin{array}{l}\text { I was learning through the internet (google). } \\
\text { Due to the environmental factor, I started to cultivate } \\
\text { vegetable commodities. } \\
\text { Because of my awareness about the importance of } \\
\text { vegetables in a healthy lifestyle. I also love cultivating } \\
\text { vegetables. } \\
\text { I love a healthy food lifestyle. } \\
\text { Due to the economical factor, I found information about } \\
\text { OvOP. I managed a partnership in distributing the OVOP } \\
\text { product. } \\
5\end{array}$ My hobby was agricultural-related. $^{2}$ \\
6 & 5 & 6
\end{tabular}


I tried to cultivate because of the existence of some chances and adequate support from the environment around me.

My family was a vegetable farmer and want to develop this business using a modern way.

I was given a chance to be a HORECA supplier.

Environmental factors and chance (hotel, restaurant, and hospital massive vegetable demand). I also enjoyed cultivating plants.

The idea started due to environmental factors (the availability of land and poor cultivating method).

I enjoyed cultivating an agricultural and I have a sufficient size of land to cultivate the vegetable commodity.

My family was distributing vegetable commodities. Then I

tried to maintain this business. I also distributed some vegetable commodities outside of Bali.

Due to the economical and environmental factors. I was also utilizing the chance provided by the market.

I was surrounded by vegetable farmers in my environment (Tabanan Regency). I participated in promoting their vegetable commodity by using the e-Commerce platform. The economical and environmental factors due to the natural disaster made me stopped working. Then I started a business by utilizing agricultural products.

It was started when I was working in a villa. The villa was needed vegetable supply for its kitchen, finally I decided to be their vegetable supplier. I was also becoming a supplier for other HORECA. Besides that, this business also helped me in maintaining my family wellness.

I loved plant, but was not like cultivating in the land that made of soil. I introduced myself to a hydroponic method and finally learned to build a business from it.

The idea to start this business appeared when my sibling who was worked as a farmer didn't sell their vegetable commodity to the market due to the drastic price drop. They said the vegetable better to be discarded than sold. Then I suggested them to sell those vegetables through an online platform (e-Commerce). In fact, so many buyers of the vegetables offered.

It started because of my healthy lifestyle and the people around me who were worked as health professionals. I was trying to cultivate hydroponic vegetables in my house to provide my self, family, and some people that need healthy vegetables for their lifestyle.

I was just trying to implement this idea because I have a knowledge in the technology field. I was also interesting with hydroponic and started to learn about the process of 
making an installation, cultivation method, and marketing segment.

The business idea appeared because I love plants. I also like trying new things.

I think agricultural commodities would very important in the future. My background was the difficulty in finding good quality of products in the tourism industry. I identified that the hindrance was the rainy season. A solution offered was the greenhouse system. The greenhouse system was successful in managing this problem, but the customer still comparing the quality of vegetable produce by this system and the conventional system. In fact, the greenhouse system didn't use chemical pesticides, therefore the risk was lower.

I built this company three years ago. At that time, I was still working on a food and beverage division in the hotel. During my recess time, I am observing the vegetable requirement in that hotel. I was planning to supply vegetables to the hotel because I also came from the vegetable supply area in Bali. Finally, I was supplying the vegetable with my older brother who was working as a vegetable farmer. At first, I only promoted this business just by word to mouth and LinkedIn platform. In 2018, I tried to promote this business through the social media platform, such as Facebook and Instagram.

I was a laundry owner in the Bali tourism area. There were many villas, restaurants, and resorts in that area. Besides supporting their laundry need, they also demanded some vegetables, fruit, and groceries for the villa's guest need. I finally decided to supply some sort of vegetables and fruits for them. I couldn't supply groceries for them due to the existence of a grocery company around my environment, I decide to work with them as well. It also helped me to expand my partnership. My marketing was more to the conventional style. It may happen due to my living place environment. I was also working as a laundry owner and notary, hence I could name my business as a one-stop shopping. My Instagram account used to reach younger customers, such as the back-office staff of a business entity. The Facebook account was also used to promote my business. The market place feature in the Facebook platform was very accommodating in promoting my fruit and vegetable. There were so many personal demand of fruit and vegetable commodity. But then, I decided to only target the company rather than the personal market because of the regular payment each month. 
26 26
I built this business because of my hobby. The basic need for food and nature preservation was also the reason for developing this business.

Trial and error factor, Wanting to try something new.

It started by the agricultural land tillage by people who came from outside of the local community (mainly focused on the agro-industrial activity). The limited amount of cultivating land that well utilized urged us to develop the land.

The reason was enjoying my hobby and desire to learn with my friends. After the harvesting period in Kintamani, we sold the commodity to the supplier.

I wanted to help the farmer in distributing the commodity to the end-user, hence the farmer more passionate about cultivating their land. I also wanted the young generation to actively participate in the agricultural field.

Source: Primary Data (Processed), 2020

Note:

* HORECA (Hotel, Restaurant, Catering)

* OVOP (One Village One Product)

Table 2 showed that the in pre-seed business, the vegetable seller e-Commerce user built the business according to their hobby and environmental factor. Rizal, et.al (2016) found that a reason for a woman to run a business was their hobby. Saragih (2017) stated that a business able to give its owner a power, spiritual awakening, and a chance to develop their hobby or interest.

Result from a study conducted by Sumadi and Sulistyawati (2017) showed that the environment positive and significantly affected the desire to build a business on the university student. Haryani (2017) also stated that the "entrepreneurship environment" was everything that existed around the entrepreneurship and affect it. In the context of developing a new entrepreneur and developing the existed entrepreneurship, the environment defined as the external environment that consisted of customer, supplier, competitor, creditor, economy, social, politics, technology, and ecology. The level of significance was different for each of these components.

More specifically, Table 2 showed that the seller had no background or experience in the agricultural field. Their strong desire and adequate support from their environment convinced them to build the business. The vegetable commodity still highly used in the tourism sector and HORECA business. Community awareness to promote a healthy lifestyle was also slowly increasing. This lifestyle highly potential to increase vegetable demand.

\section{Seed Business}

Seed was a step taken when the owner developing their idea and creativity based on their knowledge and ability to start a start-up business. The seed business participant in Bali Province is shown in Table 3. 
Table 3. Seed Business

\begin{tabular}{|c|c|c|}
\hline No. & $\begin{array}{l}\text { Participant's } \\
\text { Code Number }\end{array}$ & Seed \\
\hline 1 & 1 & $\begin{array}{l}\text { I started this business by myself. I was trying to adjust } \\
\text { the production volume needed in a year. }\end{array}$ \\
\hline 2 & 2 & $\begin{array}{l}\text { If the production volume was high, online marketing } \\
\text { through the e-Commerce platform would be chosen to } \\
\text { promote the transaction. Before running this business, all } \\
\text { the vegetables were consumed by my family and friends, } \\
\text { due to the good responses, I decided to sell this vegetable. }\end{array}$ \\
\hline & & $\begin{array}{l}\text { I was developing a vegetable garden for three years only to } \\
\text { enjoy my hobby. After that, I tried to change this hobby } \\
\text { into a business entity. I managed this business by my self. }\end{array}$ \\
\hline 3 & 3 & $\begin{array}{l}\text { I was only produced green mustard on the first three years } \\
\text { after the business built. I was using social media in the } \\
\text { initial step of the marketing process to target the } \\
\text { millennial generation. }\end{array}$ \\
\hline 4 & 4 & $\begin{array}{l}\text { I have owned a small cultivating land in Bangli, but the } \\
\text { most vegetable was coming from Denpasar City. The } \\
\text { initial marketing method was still conventional. I was only } \\
\text { using two workers. }\end{array}$ \\
\hline 5 & 5 & $\begin{array}{l}\text { I was trying to promote my vegetable commodity through } \\
\text { an online platform with my husband help. I didn't have } \\
\text { any cultivating land. }\end{array}$ \\
\hline 6 & 6 & $\begin{array}{l}\text { I started this business with my friend in my community } \\
\text { and distributed the product outside of the Denpasar area } \\
\text { with an online platform. }\end{array}$ \\
\hline 7 & 7 & $\begin{array}{l}\text { I was trying to promote my product through Instagram by } \\
\text { using hashtag. It given a massive effect on my product } \\
\text { sale. }\end{array}$ \\
\hline 8 & 8 & $\begin{array}{l}\text { I was only distributed my product to the traditional } \\
\text { market. But due to the majority of sellers promote their } \\
\text { product in the e-Commerce platform, I was also trying to } \\
\text { promote my product in the same platform. I perceived that } \\
\text { this platform brought many positive benefits to my } \\
\text { business. }\end{array}$ \\
\hline 9 & 9 & $\begin{array}{l}\text { I started this business by my self. Initially, this business } \\
\text { is done in a direct distribution method, over time I } \\
\text { changed the marketing method by promoting the } \\
\text { vegetable commodity in the online platform to broaden the } \\
\text { marketing line segment. }\end{array}$ \\
\hline 10 & 10 & $\begin{array}{l}\text { I started this business by myself. I was using e-Commerce } \\
\text { since this business started. }\end{array}$ \\
\hline 11 & 11 & $\begin{array}{l}\text { The e-Commerce used since this business built. I used } \\
\text { "yahoo" as my first platform, then I developed my own }\end{array}$ \\
\hline
\end{tabular}


website and promoted it using the Instagram eCommerce.

This business run by my family and me. The product sold in the traditional market through a conventional way, but finally an e-Commerce platform chosen to promote this product to gain a broad market network and higher price. I started this business three years ago. I sold the vegetable to some markets located in Bali and outside Bali. The vegetable was only supplied by one farmer, but now I am obtaining the vegetable from seven farmers. The mean of the cultivating land of the farmers was twohectare/farmer. Today, I am using an online platform to promote my product to broaden my market segment. I was only sold red paprika, but now I am selling many types of vegetables.

The initial promotion was using the conventional method. The consumer obtained by selling the vegetable in traditional market. This business was only involving my family.

This business started by myself with the sale source from the family. The marketing process done by e-Commerce was provided great responses and introduced me to the HORECA market segment.

I started posted the vegetable on Facebook at an attractive price. This post received many responses from the customer from the city area. Finally, I decided to run this business with my family through the e-Commerce platform.

I obtained the vegetable supply from the wholesalers, but now I am working with the direct vegetable supplier. The initial marketing method is done by using the Facebook based-e-Commerce platform. The market place feature in the Facebook used to post some photos about their vegetable commodity. Today, I am using the paid promote account to make the promoting process easier.

I started this business by making a greenhouse that consisted of seven holes. The vegetable marketing done by selling my vegetable to the seller in the market. Unfortunately, they sold my vegetable with an inappropriate price. Therefore, I tried to sell my vegetable with a higher price through posts in my social media.

I was only utilizing one supplier and promoting my business by using a personal Facebook account. The amount of my vegetable supply also still limited. Today, I am using more than one vegetable supplier and applied an e-Commerce system to target the educational 
institutions, especially student parents from the uppermiddle-class society.

Hydroponic vegetable cultivation was becoming new things in the agricultural field, hence I followed various types of training in cultivating and distributing this commodity. These trainings held by some institutions through online platforms (google). The training sessions helped me to promote my product through the online system. The vegetable harvested in the first period that having better quality was given to the doctors that routinely buying product.

I started this business in 2008. At that time, Indonesia especially Bali still was not familiar with this system. Then my business changed, from the hydroponic installation consultant to an agricultural devices provider and hydroponic vegetable supplier. The marketing process is done by using an online platform such as Facebook, Twitter, and Instagram.

I started this business individually. I promote my business around my living place and to some friends. The difficulty in setting an appropriate price for the hydroponic vegetable made me utilized the e-Commerce platform. Through this platform, I obtained a constant number of customers.

The society today had a high awareness about the healthy food. I used the e-Commerce platform due to its easy marketing system. It was easier than the door-to-door system. I was working as an investor, but due to the poor management, I tried to manage this business. I found the new market segment for this business. In 2017, there were only five workers with lettuce as the main commodity. In 2019, I created a conventional cultivating method.

I sold various types of vegetables because I supplied a restaurant that needed several types of vegetables. There was no worker involved, I worked with my family at that time. The commodity sold was produced by my family land and some of them came from some vegetable sellers around my environment. The initial promotion done by word to mouth and through LinkedIn.

I utilized two workers in the vegetable shipping process. I obtained the supply from Tiara Cokro because they stored the vegetables from 9 p.m. Hence, I could arrange more time to prepare other commodities needed. I shipped the vegetable to my customer at 6 a.m. The most important thing in this business was the accepting and shipping period. Some vegetables were easy to be withered during 
the shipping process. A good storage system during the shipping process required to maintain the vegetable condition.

This business was created individually with the help of some church volunteer at 2016 in Buleleng. The vegetable commodity was promoted through a WhatsApp group to the church member and their close family. Some church volunteers also made an Instagram account to promote the hydroponic vegetable. The vegetable distributed in some supermarkets in Denpasar City.

This business was created individually. I tried to use the Facebook based-e-Commerce platform (market place feature) to develop and help the farmer to distribute their vegetable commodity on their own marketing channel.

This business initially managed by six persons. This business could not supply many organic vegetable demand, but today this business able to introduced various of organic vegetable by using e-Commerce platform to the consumer, especially tourist.

I started this business alone, the vegetable sold to the wholesaler after the harvesting period. The first harvesting period was done on the pepper commodity at an uncertain price. The commodity produced on the next harvesting period sold to the HORECA and supermarket. Finally, we targeted the vegetable in Pancasari, Buleleng. We distributed it to the end-user and promoted it by using e-Commerce.

I started this business as an export fruit market in 2018 using the Whatsapp application. After that, a community called "petani muda keren" (cool young farmer) formed. In 2019, I started to use the Instagram application and eCommerce application that use a one-gate marketing system from the marketing process to the product order that targeted the end-user (HORECA). This system distributed all agricultural products from all regencies in Bali.

Source: Primary Data (Processed), 2020

Note:

* HORECA (Hotel, Restaurant, Catering)

The result in Table 3 showed that in the pre-seed business step, the ecommerce vegetable seller started their business due to their desire. The study from Walipah (2016) stated that in a risky and uncertain situation, the entrepreneur could take a decision that led to failure and success. The risk taken depended on their selfconfidence. Sari (2013) also stated that individual self-confidence to become an entrepreneur affected by the "positive pull", an adequate supporting-available 
condition (adequate capital, potential market, and the availability of mentor) to become of entrepreneur.

According to Table 3, in starting their business, the seller and also direct producer learned to plant their vegetable commodity in one year. After that, they were finding a constant and sustainable market. Some farmers started their business conventionally, without applying e-Commerce, but over time they started to use social-media-based e-Commerce because no-cost used in its application. But, some sellers were already using e-commerce in this step to promote their product.

\section{Start-Up Business}

On the implementation of the start-up business, the study showed that most sellers still used social media-based e-Commerce that applied a simple application module. They expect to use a system with a more complete module in the future (Indonesia Ministry of Trade, 2014). Social media was an online platform, where the user could share, participate, and create content (blog, wiki, forum, social network, virtual world room) through an internet-based application. Internet, social media, and multimedia technology was becoming a unity and shifting many innovations in the real world.

e-Commerce based-marketing also helped the seller in finding a new partnership network. Interview done on the farmer participants showed that they perceived their business developed well after using e-Commerce, unfortunately, they were not satisfied with the technology applied to the marketing process. This was parallel with Kutz (2016), that stated e-Commerce or electronic commerce was a trend in product service done by a computer network, such as the internet. The electronic trading referred to the application of technology on cellular trading, electronic money transfer, supply chain management, internet marketing, online transaction process, electronic data exchange, inventory management system, and automatic electronic data collection system. Modern electronic trading usually uses the web in all over the world to a transaction cycle, though another technology like email also sometimes used.

The mechanism of the e-Commerce applications in some type of businesses were similar, as shown in Figure 1.

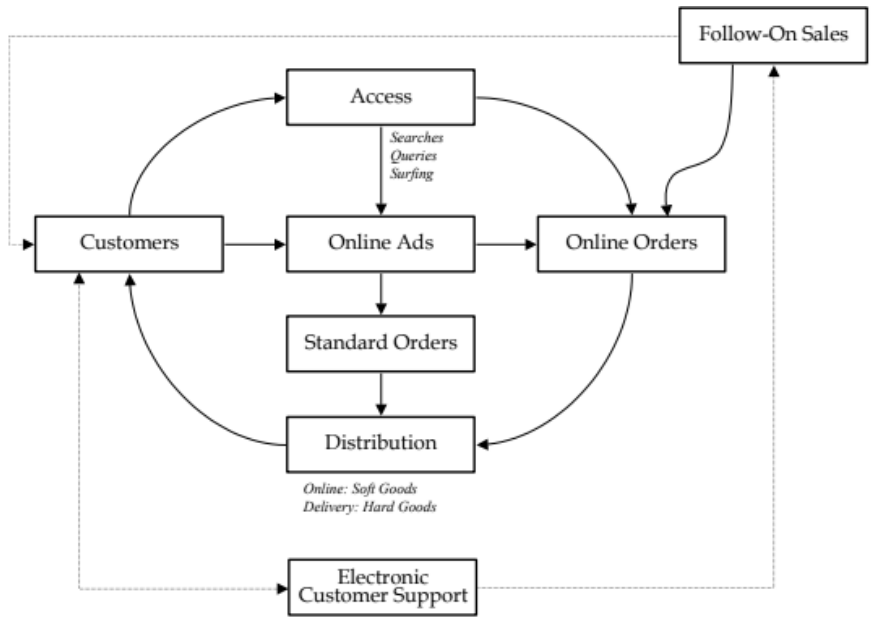

Figure 1. E-commerce Working Mechanism

Source: David Consiur (1997) in Indrajit (2002) 
The result showed that the availability of the vegetable was the hindrance in this business. The vegetable must be stocked to assure the equality between the vegetable supply and demand. Therefore, the vegetable commodity produced by the farmer also optimally distributed in the market. The business management must be well organized, especially in the level of the seller that also produced the vegetable. The agribusiness management needed to be well arranged, hence the agribusiness could produced a higher profit.

\section{CONCLUSION}

The pre-seed business developed due to the owner's hobby in the agricultural area and environmental factors that drove them to run an agribusiness. On the step of the seed business, the vegetable seller started the business according to their will. Most of the sellers still used social media-based e-commerce with a simple application module. They expect to develop a complete module system to run their e-Commerce based business in the future.

\section{RECOMMENDATION}

Long-term planning required to be conducted due to the fast development of the digital industry. The plan designed must be anticipated the threats and technological changes in the future. Study about the social media role in the agribusiness also required to be conducted due to the farmer limitation in using technological devices. Most farmers were only able to operate social media to promote their agricultural products.

\section{REFERENCES}

Antara, M., Astuti, L. S. and Madiun, I. N. (2017) E-Marketing Pemasaran Villa Menggunakan Online Travel Agents. 1st edn. Edited by M. Antara, L. S. Astuti, and I. N. Madiun. Denpasar: Pelawa Sari.

Apriadi, D. and Saputra, A. Y. (2017) 'E-Commerce Berbasis Marketplace Dalam Upaya Mempersingkat Distribusi Penjualan Hasil Pertanian', Jurnal RESTI (Rekayasa Sistem dan Teknologi Informasi), 1(2), pp. 131-136. Available at: http://jurnal.iaii.or.id.

Haryani, S. (2017) 'Pengaruh Lingkungan Kewirausahaan Terhadap Pengembangan Wirausaha Di Kabupaten Sleman', EKUITAS (Jurnal Ekonomi dan Keuangan), 1(1), pp. 24-43. doi: 10.24034/j25485024.y2017.v1.i1.1841.

Indrajit, R. E. (2002). Electronic Commerce-Strategi dan Konsep Bisnis di Dunia Maya. Retrieved from https://repository.unikom.ac.id/48010/1/Electronic Commerce-Strategi dan Konsep Bisnis di Dunia Maya.pdf

Kemendag RI. (2014). Panduan Optimalisasi Media Sosial (1st ed.; H. W. Satria \& L. H. Arifin, Eds.). Jakarta Pusat: Pusat Humas Kementrian Perdagangan RI.

Kutz, M. (2016). Indroduction to E-Commerce: Combining Business and Information Technology (1st ed.). Retrieved from https://bookboon.com/en/introductionto-e-commerce-ebook 
Nugraha, A. E. P. and Wahyuhastuti, N. (2017) 'Start Up Digital Business: Sebagai Solusi Penggerak Wirausaha Muda', Jurnal Nusantara Aplikasi Manajemen Bisnis, 2(1), pp. 1-9. Available at: Ojs.unpkediri.ac.id/index.php/manajemen.

Perdani, M. D. K., Widyawan and Santoso, P. I. (2018) 'Faktor-faktor yang mempengaruhi pertumbuhan startup di yogyakarta', Seminar Nasional Teknologi Informasi dan Komunikasi 2018, pp. 23-24.

Rizal, M., Setianingsih, D. and Chandra, R. (2016) 'Faktor-faktor yang Mempengaruhi Wanita Berwirausaha (Studi Kasus di Kota Langsa)', Jurnal Manajemen dan Keuangan Unsam, 5(2), pp. 525-534.

Saragih, R. (2017) 'Membangun Usaha Kreatif, Inovatif Dan Bermanfaat Melalui Penerapan Kewirausahaan Sosial', Jurnal Kewiraushaan, 3(2), pp. 50-58.

Sari, N. M. A. T. (2013) 'Pengaruh Pelatihan, Sikap, Intensi, Dan Modal Terhadap Perilaku Berwirausaha Pada Peserta Program Mahasiswa Wirausaha', Jurnal Pendidikan Ekonomi, 1(1), pp. 64-76.

Silalahi, S. A. F. (2017) 'Perkembangan Dan Tantangan Perusahaan Start-Up Nasional', Majalah Info SIngkat Ekonomi dan Kebijakan Publik, pp. 13-16.

Sumadi, A. R. and Sulistyawati, E. (2017) 'Pengaruh Sikap, Motivasi, dan Lingkungan Terhadap Niat Berwirausaha', Jurnal Manajemen Unud, 6(2), pp. 1007-1029.

Walipah (2016) 'Faktor - Faktor Yang Mempengaruhi Niat Berwirausaha Mahasiswa', Jurnal Ekonomi Modernisasi, 3(12), pp. 138-144. doi: http:// dx.doi.org/10.21067/jem.v12i3.1461. 